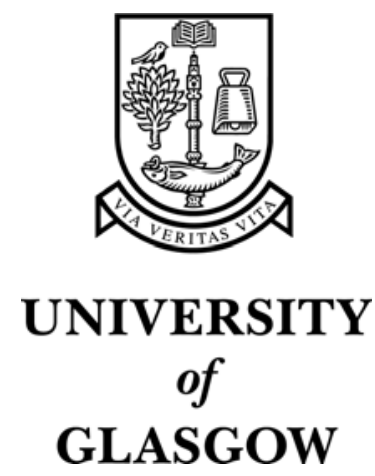

Brown, D. (2001) The church and the origins of Scottish independence in the twelfth century. Records of the Scottish Church History Society 31:pp. 1-34.

http://eprints.gla.ac.uk/3708/ 


\section{The Church and the origins of Scottish independence in the twelfth century DAUVIT BROUN, B.A., Ph.D.}

Scotland's status in relation to England is one of the most emotive issues for a Scottish historian to confront. Professional historians in recent times, both Scottish and English, have generally tried to navigate their way through the subject without taking bearings from the blazing beacon of patriotism; nonetheless it is almost impossible to avoid being picked up in its glare by readers suspicious of a scholar's studied objectivity. ${ }^{1}$ History has repeatedly been invoked as the proving ground by those with entrenched views; and, when the evidence can not be reconciled with a particular position, it has all too readily been modified to ensure that the cogency of a predetermined story-line is undisturbed. In the late seventeenth century, or shortly after, someone even went so far as to destroy what he considered to be an especially disagreeable piece of evidence. The victim of this act of vandalism was a brief passage in the Chronicle of Melrose, the only chronicle from Scotland in the twelfth and thirteenth centuries that survives in the manuscript in which it was originally written. ${ }^{2}$ Under the year 1072 it was noted in the Chronicle that Mael Coluim Cenn Mór, king of Scots, when he met with William the Conqueror at Abernethy, 'became his man'. ${ }^{3}$ This explicit statement in a Scottish source of a Scottish king's vassalage to a king of England was too much for our reader to bear; in desperation he scraped away completely the dreadful words homo suus devenit, 'became his man', leaving an ugly blank space and an incomplete sentence. The original

\footnotetext{
The plight of the historian on this issue is described with slightly pained indignation in Anglo-Scottish Relations 1174-1328, ed. and trans. E. L. G. Stones (London 1965; reprinted Oxford 1970), xviii-xx.

2 The Chronicle of Melrose from the Cottoniam Manuscript, Faustina B ix in the British Museum: a complete and full-size facsimile in collotype, edd. Alan Orr Anderson and Marjorie Ogilvie Anderson, with index by William Croft Dickinson (London 1936) [hereafter Chron. Melrose].

3 Chron. Melrose, 28; xxxiv.
} 
reading, however, has been preserved in the first printed edition of the Chronicle, published in $1684 .{ }^{4}$

It is a commonplace to say that any attempt to reconstruct the past is governed by the automatic assumptions or conscious concepts on which an author depends. It is easy to point to the limitations of a partisan telling of Scoto-English relations; it is far less straightforward to criticise a scholarly construct which has carried the weight of generations of books and papers. As far as the relationship between Mael Coluim Cenn Mór and William the Conqueror and their successors is concerned, historians have interpreted this within a conceptual framework which has been in the scholarly bloodstream before History was first taught in its own right in universities. This framework is feudalism. The essence of what feudalism means and how this has been used in the context of the relationship between kings of Scots and kings of England may be illustrated by referring to a book on medieval Scotland published in 2000. It is explained there that: ${ }^{5}$

Feudalism was essentially a system of personal relationships. At the upper levels of society these normally took the form of a grant of land by a superior lord, often the king, to someone termed a vassal, who did homage and swore fealty to the lord, in effect promising to 'be his man' and to be faithful to him, and undertook to perform specified services which were normally (though not always) of a military nature, such as service in war and the performance of garrison duty in castles.

It is then envisaged that the submission of Mael Coluim Cenn Mór to William the Conqueror at Abernethy in 1072 was seen by the English king as constituting a feudal relationship: ${ }^{6}$

This was later taken as evidence of the feudal subjection of the Scottish monarchs to their English counterparts, and there can be little doubt that William saw it in this light, but no reason to suppose that Malcolm chose to interpret his submission in these terms.

\footnotetext{
4 William Fulman, Rerum Anglicarum Scriptorum Veterum, vol.i (Oxford, 1684), at 160.

5 A. D. M. Barrell, Medieval Scotland (Cambridge 2000), 16.

6 Ibid., 70.
} 
There is nothing particularly unusual about these statements. Feudalism has regularly been represented by Scottish historians as a Norman import brought to England by the Conquest of 1066; it would hardly seem controversial, then, to imagine that William thought in feudal terms when Mael Coluim became his man in 1072, or to assume that Mael Coluim, because he may not have been familiar with Norman ways, might not have been aware of the full implications of his action. The next generation of Scottish kings, the sons of Mael Coluim Cenn Mór, however, are typically regarded as acquiring some knowledge of feudalism during their enforced stay in England following their uncle Domnall Bán's taking of the kingship in 1093. This is deemed to have been especially true for the youngest, David, who was nurtured at the English royal court and developed a close relationship with Henry I.

It is has seemed quite natural, then, to interpret the relationship between kings of Scots and English in feudal terms, on the implicit understanding that this was how it would have been understood by both parties once Edgar, son of Mael Coluim Cenn Mór, defeated and captured Domnall Bán in 1097 and became securely established as king of Scots. Accordingly, it has been taken as read that the manifest subordination of Edgar and Alexander I to William Rufus and Henry I of England meant that these kings of Scots were vassals who held Scotland from the king of England.? Indeed, in a charter of Edgar, whose authenticity has recently been vindicated by Professor Duncan, it was (apparently) declared that Edgar held 'the land of Lothian and the kingdom of Scotland' not only by paternal inheritance but by the gift of his lord King William of England. ${ }^{8}$ Alexander I, for his part, fought in Henry I's campaign in Wales in 1114. This was an enterprise in which Alexander could have had no personal interest beyond his relationship with the king of England. ${ }^{9}$ In contrast, the fact

For example, W. Croft Dickinson, rev. A. A. M. Duncan, Scotland from Earliest Times to 1603 (Oxford, 1977), 60-1; A. O. Anderson, "Anglo-Scottish relations from Constantine II to William”, SHR, 42 (1963), 1-20, at 11-13.

8 A. A. M. Duncan, Scotland: the Making of the Kingdom (Edinburgh, 1975; repr. with addenda, 1978), 125.

9 He and Richard, earl of Chester, are named as the leaders of a force from Scotland and northern England, one of three divisions which made up Henry's army. Alexander and Richard made their way into the heartlands of Gwynedd and Powys 
that David I never paid homage to King Stephen (1135-54) has been interpreted as an assertion of Scotland's independence. ${ }^{10}$ The relationship thereafter between kings of Scots and kings of England has generally been presented as fluctuating from English feudal superiority to Scottish independence according to the relative strength and weakness of each king, with the added complication that, when the king of Scots held the earldom of Huntingdon of the king of England, it was possible to interpret homage as for lands in England alone, leaving Scotland out of the equation. The potential ambiguity of that situation, and the clear instances of kings of Scots who were client kings, and of others who operated as independent monarchs, has for centuries supplied grist to the mill to partisans on both sides, each picking what seemed most compelling for their case.

There is a problem, however. Susan Reynolds, in her book Fiefs and Vassals: the Medieval Evidence Reinterpreted (1994), has undertaken a searching examination of the sources which are held to sustain feudalism as an interpretative paradigm. Her conclusion is that this imposing intellectual edifice, inhabited by historians for centuries, is built on sand. She argued that 'the concepts of vassalage and of the fief ... as they have been developed since the sixteenth century, originated in the work of the sixteenth-century scholars rather than in the late medieval texts they studied'; as a result, 'what the concept of feudalism seems to have done since the sixteenth century is not to help

and negotiated the submission of Gruffudd ap Cynan, king of Gwynedd, to Henry I. Brut y Tywysogyon or The Chronicle of the Princes. Peniarth MS. 20 Version, trans. Thomas Jones (Cardiff, 1952), 37-8; Brut y Tywysogyon or The Chronicle of the Prices. Red Book of Hergest Version, ed. and trans. Thomas Jones (Cardiff, 1955), 78-81; Brenhinedd y Saesson or The Kings of the Saxons, ed. and trans. Thomas Jones (Cardiff, 1971), 120-3. See C. P. Lewis, "Gruffudd ap Cynan and the Normans", in Gruffudd ap Cynan. A Collaborative Biography, ed. K. L. Maund (Woodbridge, 1996), 61-78, at 74; R. R. Davies, Conquest, Coexistence and Change: Wales 10631415 (Oxford, 1987) (republished as The Age of Conquest. Wales 1063-1415 (Oxford, 1991)), 42.

10 G. W. S. Barrow, Kingship and Unity. Scotland 1000-1306 (London, 1981), 37; or it has been seen less dramatically as a lapse in the previous state of feudal subjection (Dickinson, rev. Duncan, Scotland from Earliest Times to 1603, 66); it has also been denied that independence or subjection was uppermost in David's mind, and that his chief concern was his oath to accept Matilda as queen (Anderson, “Anglo-Scottish relations”, 15 n.1). 
us recognise the creatures we meet [in contemporary sources] but to tell us that all medieval creatures are the same so that we need not bother to look at them. ${ }^{11}$ When historians have found evidence in a particular case which told against the universal applicability of what was assumed to constitute feudalism, there has been a tendency to regard this as a deviation from the norm, rather than to challenge the validity of the supposed norm itself. ${ }^{12}$

Where does this leave feudalism in Scotland? Susan Reynolds did not include Scotland in her discussion, and there have been few statements to date about how her ideas might fare in a Scottish context. ${ }^{13} \mathrm{~A}$ more long term response would be to embark on a fresh examination of the 'creatures we meet in contemporary sources' to see how social and political relationships operated in different contexts. It is unlikely, as Reynolds has argued, that the result of this research will be the identification of anything so consistent and central that it might merit the status of an '-ism'. It is equally likely, however, that some social relationships will be recognised as corresponding closely with what have been regarded as core features of feudalism. A more rounded and nuanced understanding of Scottish society in the twelfth and succeeding centuries may be likely to emerge at the end of this process; but it will almost certainly retain key elements that would be

\footnotetext{
11 Susan Reynolds, Fiefs and Vassals: the Medieval Evidence Reinterpreted (Oxford, 1994), 6, 11.

${ }_{12}$ An exception as far as Scottish studies are concerned is an unpublished paper by Grant Simpson based on his study of non-royal grants to individuals (chiefly in the thirteenth century). This was delivered at the annual Conference of Medieval Scottish Historical Research at Pitlochry in January 1986. It has been claimed that it was greeted by a 'wall of polite silence' on that occasion: Richard D. Oram, "Gold into Lead? The State of Early Medieval Scottish History", in Freedom and Authority. Scotland c.1050-c.1650. Historical and Historiographical Essays presented to Grant G. Simpson, edd. Terry Brotherstone and David Ditchburn (East Linton, 2000), 32-43, at 37. This does not tally with my recollection of the event.

${ }^{13}$ A brief uncompromising defence of the validity of feudalism as a term applicable to Scotland in the twelfth century is G. W. S. Barrow, "Scotland's experience of feudalism in the twelfth century", History Teaching Review Year Book. The Year Book of the Scottish Association of Teachers of History, 14 (2000), 5-9. In contrast, approval for the potential validity of Reynolds' ideas in a Scottish context has been expressed in Oram, “Gold into Lead?" in Freedom and Authority, edd. Brotherstone and Ditchburn, 37.
} 
instantly recognisable to the older generation of scholars who worked so comfortably (and profitably) within the world of feudalism. ${ }^{14}$

As far as the specific issue of the relationship between kings of Scots and kings of England is concerned, however, we are in the happy situation that this has already formed part of an innovative reexamination. Rees Davies, in the third of his Wiles lectures delivered in 1988, had already moved away from the 'feudal paradigm' when he turned his attention to the subject of royal submissions to the king of England in the period (roughly) between 1100 and $1300 .{ }^{15}$ He was able, by adopting a British rather than simply a Scottish perspective, to show that subordination did not initially mean that the client ruler was deemed to hold his realm of the king of England in return for military service. The English king was generally content simply to enjoy (and occasionally enforce) the deference of other rulers in Britain without actually seeking to conquer them or impose a strictly tenurial relationship. When Professor Davies elaborated on this point in the published version of his lectures, he explained it as a reflection of what he described as the 'very occasional and marginal interest that English kings showed in the outlying areas of the British Isles' ${ }^{16}$ As far as the twelfth and thirteenth centuries as a whole was concerned, the power of English kings, he argued, 'was variable in its attention and its intensity; it could appear detached, almost uninterested, in one decade, surprisingly interventionist in the next'. He highlighted the first twenty years of the reign of Henry II as 'one period in which the king of England pressed his claim to lordship of the British Isles vigorously' ${ }^{17}$ But he also saw a qualitative change in the thirteenth century, when claims to jurisdictional superiority 'come to occupy

\footnotetext{
14 The first detailed reexamination likely to reach the public domain of what would, in the past, have been regarded as 'feudal society', is Nigel Webb, "Settlement and Integration in Scotland 1124-1214. Local Society and the Development of Aristocratic Communities: with Special Reference to the Anglo-French Settlement of the South East”, University of Glasgow Ph.D. Dissertation, which is at an advanced stage of preparation.

15 R. R. Davies, Domination and Conquest: the Experience of Ireland, Scotland and Wales 1100-1300 (Cambridge, 1990), 47-65, esp. 56-62.

16 Ibid., 68.

17 Ibid., 75.
} 
centre stage in the definition of relationships between suzerain and client in the British Isles'. ${ }^{18}$

Professor Davies developed these points further in a paper published in 1996. ${ }^{19}$ A slight, but significant modification to his earlier discussion was that, instead of headlining the intensity of the English king's interest as the most prominent feature, he now emphasised the nature of the relationship between the king of England and his 'Celtic' neighbours. The degree of attention devoted by a king of England to other rulers in Britain and Ireland remained an important political factor. These relationships, however, usually conformed to a pattern, and it was this which was highlighted by Professor Davies in his 1996 paper. He also sharpened his focus on how the pattern of these relationships was transformed by the development of jurisdictional superiority, pinpointing the 'Treaty of Falaise' between King William and King Henry II in 1174 as initiating a new phase the first occasion in which the independence of a subordinate kingdom was challenged directly and systematically. As before, immediate political considerations were crucial in determining the reality of these relationships. The framework within which they operated had, however, changed fundamentally.

These clarifications by Professor Davies are the inspiration for this paper. I will argue that it is now possible to talk with some precision about the origins of Scottish independence: that is, when the status of the Scottish kingdom vis-à-vis England first became an issue in relation to the exercise of authority over Scottish society. There are some details, however, that will have to be tackled before this point is reached. In particular, it needs to be established that the 'feudal' model did not apply to the relationship between kings of Scots and kings of England at least as early as the 1090s. The burden of this paper, however, is that the issue of Scottish independence did not initially arise in the context of royal relations, but has its origins in the rebirth of the Church as a fully articulated unified institution whose

\footnotetext{
18 Ibid., 103; in general, see esp. 100-6.

19 Rees Davies, "'Keeping the natives in order': the English king and the 'Celtic' rulers 1066-1216”, Peritia, 10 (1996), 212-24. For a summary of the key points here and in his earlier discussion, see R. R. Davies, The First English Empire. Power and Identities in the British Isles 1093-1343 (Oxford, 2000), ch. 1, esp. 20-1.
} 
authority embraced all of Latin Christendom. It was as part of this process that Scottish independence was first asserted in a text whose authenticity has only recently been established by the discovery of two manuscript witnesses.

The springboard for this paper, as I have indicated, is Professor Davies's identification of a fundamental change in the nature of the relationship between kings of England and their 'Celtic' neighbours in the late twelfth century. Professor Davies has summarised this development in these words: ${ }^{20}$

If one wishes to simplify it one can characterise it as a shift from a patriarchal overlordship to what was, at least occasionally and potentially, a more direct, bureaucratic and interventionist overlordship.... The outcome was by no means certain and was in fact to be very different indeed in Scotland, Ireland and Wales; but if my interpretation carries any plausibility the nature of the challenge was becoming clear by 1216. It was a challenge which involved, to a greater or lesser degree, the conversion of an essentially loose overlordship into a more direct lordship, of moving from extensive authority towards, though falling far short of reaching, intensive authority.

Professor Davies in the same paper provided a compelling account of 'patriarchal' or 'loose' overlordship. Typically it involved not only a display of power by the king of England, such as his intervention in a disputed succession (as in William II's backing of Edgar against Domnall Bán), or, most brutally, a full scale invasion (which is how William I forced Mael Coluim to meet him at Abernethy in 1072), but also some face-to-face discussion between the principal parties leading to the establishment of friendship and peace. The process was completed by a public act of submission. Professor Davies emphasised that submission was 'essentially personal; it was not a treaty between states, nor was land mentioned' ${ }^{21}$ It would be misleading to refer to a 'Treaty of Abernethy' in 1072. ${ }^{22}$ Meaning was conveyed by potent rituals and gestures. An important consequence of this was that,

Davies, “Keeping the natives in order”, 223.

Ibid., 215.

As, for example, in M. Brett, The English Church under Henry I (Oxford, 1975), 15. 
although the essential fact of the king of England's power had been unambiguously acknowledged, the detail of what might be involved could be open to more than one interpretation, and would not, in any case, be regarded explicitly as defining the relationship for ever and anon. In Rees Davies's words: 'these men were involved in defusing the crisis of the moment, not in composing footnotes in future textbooks of constitutional history'. ${ }^{23}$ An essential feature of these submissions which Davies has identified is that, if they were to endure at all, 'the client must be made to feel that he was being treated as a friend not as a door mat'. ${ }^{24}$ There would, usually, be demands made on the king who submitted, for example the surrender of hostages and payment of tribute. But there would also be important benefits for a king who enjoyed the friendship of a more powerful neighbour. He might expect that his own prestige 'at home' would be enhanced by such an association with a great ruler; indeed, he might need the support of the king of England in order to secure his own position as king against his rivals. It is this in particular which justifies the description of the king of England's overlordship as 'patriarchal'. It was also a 'loose' overlordship because there was no expectation that the king of England would cut across the client king's authority within his own kingdom. Far from being a threat to the client king's power over the people he ruled, the expectation was that the king of England

23 Davies, “Keeping the natives in order”, 215.

24 Ibid., 216. This is not to say that some rulers did not suffer from harsh treatment. A particularly striking case is the way Henry I dealt with Iorwerth ap Bleddyn, who in 1103 was tried at Shrewsbury by the king's council, convicted and imprisoned, and was only released when Henry 'remembered' that he was still incarcerated. In Welsh chronicles (which, it should be remembered, are derived from a Latin archetype written after the Edwardian conquest) Iorwerth is credited with a speech which gives a graphic account of the humiliation of the Welsh under Henry (Brut y Tywysogyon... Peniarth MS. 20 Version, trans. Thomas Jones, 26, 32; Brut y Tywysogyon... Red Book of Hergest Version, ed. and trans. Thomas Jones, 48-9, 66-7; Brenhinedd y Saesson, ed. and trans. Thomas Jones, 100-1, 110-13 (but without Iorwerth's speech). On Henry's relationship with Iorwerth, 'the most powerful of the Powys princelings', see R. R. Davies, "Henry I and Wales", in Studies in Medieval History Presented to R. H. C. Davis, edd. H. Mayr-Harting and R. I. Moore (London, 1985), 133-47, at 139, 141. This was during a particularly confused period for Powys, with Iorwerth and his two brothers vying for control: see Kari Maund, The Welsh Kings (Stroud, 2000), 86-90. 
would, if anything, help to make this more secure. In Rees Davies's words, submission 'inaugurated, formalised or continued what we may define as essentially a non-penetrative overlordship' ${ }^{25}$

25 Davies, "Keeping the natives in order”, 217. It has been suggested that William II 'may have been seeking to enforce a stricter interpretation of his overlordship than Malcolm was prepared to allow' when the two kings failed to settle their differences at Gloucester on 24 August, 1093: Judith Green, "Anglo-Scottish relations, 10661174", in England and her Neighbours 1066-1453. Essays in Honour of Pierre Chaplais, edd. Michael Jones and Malcolm Vale (London, 1989), 53-72, at 58. Many other scholars have similarly seen the abortive meeting at Gloucester in this light (including, among those named below, Aird and Scott). The source for this incident has recently been re-edited: The Chronicle of John of Worcester, vol.iii, ed. and trans. P. McGurk (Oxford, 1998), at 64-5; it has been argued that this is an accurate record: W. W. Scott, "The March Laws reconsidered", in Medieval Scotland. Crown, Lordship and Community: Essays Presented to G. W. S. Barrow, edd. Alexander Grant and Keith J. Stringer (Edinburgh, 1993), 114-30, at 121. We are told that William insisted that Mael Coluim should 'do right to him' (rectitudinem ei faceret) according to the judgement of his (William's) court; Mael Coluim refused, stating that he would only accept the judgement of the leading men of both kingdoms and 'do right' (rectitudinem facere) to William on the frontier of their kingdoms, as was customary. McGurk's translation unfortunately has 'homage' rather than 'right' (preferred by Scott, and Aird, cited below), which rather prejudges the matter. Regrettably it is not clear what was immediately at issue. The most plausible suggestion is that William objected to Mael Coluim's plans for the marriage of his daughter, Edith (then housed in Wilton nunnery) to Alan of Brittany and Richmond, or that William had plans to marry her himself (Frank Barlow, William Rufus (London, 1983), 310-16); an earlier suggestion was that William had reneged on an agreement (1091) to restore property and revenue in England to Mael Coluim (e.g. Anderson, "Anglo-Scottish relations", 12; Duncan, Scotland: the Making of the Kingdom, 121). It has frequently been said that the immediate cause of the dispute was that Mael Coluim was aggreived at William's seizure of Carlisle in 1092 (e.g. recently W. M. Aird, "Northern England or Southern Scotland? The Anglo-Scottish border in the eleventh and twelfth centuries and the problem of perspective", in Government, Religion and Society in Northern England 1000-1700, edd. John C. Appleby and Paul Dalton (Stroud, 1997), 27-39, at 28; see also J. G. Scott, "The partition of a kingdom: Strathclyde 1092-1153", Transactions of the Dumfriesshire and Galloway Natural History and Antiquarian Society, $3^{\text {rd }}$ series, 72 (1997), 11-40, at 16, who points out that Mael Coluim's insistence on a border conference would have required recognition of where the border was.) According to the Anglo-Saxon Chronicle (MS E) (A. O. Anderson, Scottish Annals from English Chroniclers, A.D. 500-1286 (London, 1908; repr. with corrections, Stamford, 1991) [hereafter SAEC], 109), the meeting was at William's insistence, who sent hostages to Mael Coluim. If it was William who felt wronged (as may be inferred from the sources), then the 
To what extent can these general observations be said to apply in the case of relations between kings of Scots and kings of England before the change to a more direct, interventionist overlordship identified by Davies? Older generations of historians might have objected, for instance, that in the twelfth century kings of Scots, unlike their Welsh and Irish counterparts, would have been familiar with feudal ideas, and that this would have influenced the nature of their dealings with their powerful southern neighbour. As backing for this, it might be protested, one could not deny the statement in Edgar's charter that the kingdom of Scotland had been given to him by his lord, King William II of England—a clear case, it would seem, of a link between subordination and tenure.

This is, indeed, a crucial document, and needs to be considered carefully. On closer inspection, it is far from clear in the charter's prose that William as Edgar's lord was deemed to have given the kingdom of Scotland to his vassal. ${ }^{26}$ The crucial passage reads: ${ }^{27}$

Edgarus filius Malcolmi regis Scottorum totam terram de Lodeneio et regnum Scotie dono domini mei Willelmi Anglorum regis et paterna hereditate possidens.

'Edgar, son of Mael Coluim king of Scots, possessing the entire land of Lothian and the kingdom of Scotland by the gift of my lord William king of the English and by paternal heritage'.

Professor Duncan, in his defence of the charter against the charge that it is a later forgery, has pointed out that 'one could not possess something both by gift and by inheritance' ${ }^{28} \mathrm{He}$ concluded, therefore,

marriage of Mael Coluim's daughter might indeed have been the issue (as Barlow suggested). Perhaps the dispute hinged on who ultimately had authority over Edith, which could readily have developed into a difference over procedure.

${ }^{26}$ The charter was almost certainly drafted and produced by the beneficiary, the monks of Durham.

27 The best edition is in A. A. M. Duncan, "Yes, the earliest Scottish charters", SHR, 78 (1999), 1-38.

${ }^{28}$ Ibid., 30. This is an important modification of his earlier interpretation in A. A. M. Duncan, “The earliest Scottish charters”, SHR, 37 (1958), 103-35, at 129-31. The most coherent attack on the charter's authenticity is J. Donnelly, "The earliest Scottish charters?”, SHR, 68 (1989), 1-22. See also G. W. S. Barrow, The AngloNorman Era in Scottish History (Oxford, 1980), 153 n.42. 
that this passage 'must mean that Edgar possessed all Lothian by Rufus's gift and regnum Scotie by inheritance'. He noted a similar contrast between land held as a grant and land possessed by paternal heritage in a charter of Duke Richard II of Normandy. The distinction between Lothian and Scotland in the charter therefore becomes crucial. Although it seems artificial today, it is exactly what should be expected in the 1090s. Indeed, it was still possible at the beginning of the thirteenth century for someone to regard Scotland and Lothian as distinct, and for another to describe the Forth as dividing the kingdom of Scots from the kingdom of the English. ${ }^{29}$ In this light it is readily understandable that Lothian could be regarded as within the king of England's gift. The date of the charter, 1095, has nourished the greatest doubts about its authenticity, for there is no evidence that Edgar possessed the kingdom of Scotland at this stage: it was not until 1097 that Edgar drove his uncle from the kingship in an invasion supported by William Rufus. Professor Duncan has pointed out, however, that regnum in this period can readily be translated as 'kingship', referring to office or status, rather than 'kingdom', which implies territory. The statement that Edgar 'possesses the whole land of Lothian and the kingship of Scotland' can therefore be seen as saying merely that he had royal status as well as possessing Lothian. ${ }^{30}$ Indeed, such an interpretation is invited by the contrast between terra, 'land', and regnum, 'kingship'.

It would not appear, therefore, that Edgar's dependence on William Rufus was regarded as establishing a formal tenurial

29 Dauvit Broun, "Defining Scotland and the Scots before the wars of independence", in Image and Identity: the Making and Remaking of Scotland through the Ages, edd. Dauvit Broun, Richard J. Finlay and Michael Lynch (Edinburgh, 1998), 4-17, at 6-7; idem, "The seven kingdoms in De situ Albanie: a record of Pictish political geography or imaginary map of ancient Alba?”, in Alba. Celtic Scotland in the Middle Ages, edd. E. J. Cowan and R. Andrew McDonald (East Linton, 2000), 2442, at 29.

30 Duncan, "Yes, the earliest Scottish charters", 30-2. One might add that, from the point of view of the beneficiary of the charter (the cathedral priory of Durham, where the text was presumably drafted), they may have anticipated that Lothian would by ruled by the king of Scots (as had usually been the case for over a century); they may therefore have been keen that Edgar's kingship be specified in the hope that the terms of the charter would more readily be accepted by Edgar and his successors should he succeed in ousting his uncle, Domnall Bán, from the throne. 
relationship involving the Scottish kingship. There need be less doubt, moreover, that his successor Alexander I regarded his freedom to control his own kingdom as unaffected by his client relationship with Henry I. The reason for this is that a contemporary writer has left a detailed account of his dealings with Alexander in which a key element was Alexander's view of his own kingship. The writer was Eadmer, who in his Historia Novorum reported and explained the events of his brief career in Scotland as bishop-elect of St Andrews from 1120 to $1121 .{ }^{31}$ Eadmer had a wretched time. He was a monk of Canterbury, and a passionate advocate of Canterbury's claim to lead the Church throughout Britain. He was head-hunted by King Alexander, who arranged with the archbishop of Canterbury that Eadmer could be released to serve as episcopus Scottorum, 'bishop of Scots' (which is how bishops of St Andrews were designated). It was only after Eadmer had arrived, however, that it became clear that Alexander and he had fundamentally different views about the status of the bishop of the Scots. Eadmer held firm to his obedience to Canterbury, and asked that he might be consecrated there; Alexander, however, according to Eadmer, declared 'that he would never in his life consent that a Scottish bishop should be subject to the bishop of Canterbury', and insisted 'that the kingdom of Scotland owed no subjection to the church of Canterbury' ${ }^{32}$ Relations between the two men broke down completely. In desperation, Eadmer asked for advice from Bishop John of Glasgow and two monks of Canterbury who were with him. Eadmer's record of their assessment of the situation includes this graphic statement about King Alexander: ${ }^{33}$

We know the man. He wishes in his kingdom to be all things alone, and will not endure that any authority have the least power in any matter, without his control.

\footnotetext{
31 Eadmeri Historia Novorum in Anglia, ed. Martin Rule (Rolls Series, London, 1884). An important discussion of this work is Sally N. Vaughn, "Eadmer's Historia Novorum: a Reinterpretation”, in Anglo-Norman Studies X: Proceedings of the Battle Conference, 1987, ed. R. Allen Brown (Woodbridge, 1988), 259-89.

32 Eadmeri Historia Novorum, ed. Rule, 284; SAEC, 143.

33 Eadmeri Historia Novorum, ed. Rule, 285; SAEC, 144.
} 
Eadmer was not an impartial observer in all this, of course. His portrayal of Alexander as both intransigent and exasperated could not be regarded as a complete picture of Alexander's character (and might equally be said of Eadmer himself). There is no need to doubt, however, that Eadmer has correctly reported the issues which lay at the heart of his dispute with the king: Alexander's insistence that he would not share authority over his kingdom with the archbishop of Canterbury or anyone else. ${ }^{34}$ In the light of this, it is inconceivable that Alexander would, for example, have led a contingent to fight in Henry I's invasion of Wales had this implied any diminution of his independence as ruler of his kingdom. There is no doubt, however, that he was prepared to recognise the reality of Henry's power compared to his own. This not only took the form of military service, but also Alexander's marriage to Henry's illegitimate daughter, Sybil, which, it has been suggested, may have been arranged when the two kings were in Wales in $1114 .{ }^{35}$ Such a match clearly indicated the inferior standing of the king of Scots. There is no reason to doubt that Alexander regarded his marriage in a positive light as marking friendly relations with Henry I. ${ }^{36}$ Indeed, Alexander may have seen this as particularly welcome, given Henry I's close relationship with Alexander's brother David, who was not only a potential rival, but had won control of most of what is now southern Scotland despite Alexander's opposition. ${ }^{37}$

34 Compare John of Salisbury's report (in a letter to John of Canterbury, bishop of Poitiers, c. May1168) of Henry II's exclamation that 'now at last he [had] secured the authority of his grandfather [Henry I], who was king in his own land, papal legate, patriarch, emperor, and everything he wished...': Letters of John of Salisbury, vol.ii, ed. W. J. Millor and C. N. L. Brooke (Oxford, 1979), 580-1, cited in Henry Summerson, "Kingship, government, and political life, c.1160-c.1280", in The Twelfth and Thirteenth Centuries 1066-c.1280, ed. Barbara Harvey (The Short Oxford History of the British Isles) (Oxford, 2001), 201-40, at 210.

35 Judith A. Green, "David I and Henry I”, SHR, 75 (1996), 1-19, at 9.

36 Alexander's marriage has often been viewed negatively by Scottish historians; it has even been claimed that Alexander was 'deliberately humiliated' (Gordon Donaldson, Scotland: the Shaping of a Nation (London, 1974), 28). This would only make sense, however, if it was assumed that Alexander regarded himself as Henry I's equal (which he obviously did not).

${ }^{37}$ Ibid., 3. For a contemporary view of David as divisive, see Thomas Owen Clancy,

“A Gaelic polemic quatrain from the reign of Alexander I, ca. 1113”, Scottish Gaelic 
As far as this early period of submission of kings of Scots to kings of England is concerned, therefore, it is clearly misleading to view this in terms of the 'feudal' contruct deployed by so many generations of scholars. Our understanding has been obscured by the assumption that the existence of one element in the historian's checklist of essential features of a feudal relationship-homage, knight service, and holding land of one's lord — should be regarded as evidence that all these features were potentially in operation. Neither kings of England, nor kings of Scots, regarded Scotland as a feu granted by the king of England in return for military service; moreover, neither party would have thought of their relationship as defined in detail in a way that was necessarily meant to endure. Sure, a king of England would (except in unusual circumstances) be considerably more powerful than a king of Scots, and could quite naturally be regarded as the leading king in Britain. But the specifics of what a particular submission entailed would not have been imagined as constituting a permanent arrangement.

As long as submission and subservience to kings of England was seen in 'feudal' terms it seemed natural to regard this as representing a loss of independence. A central point in Professor Davies's reassessment, however, is that client kings retained their independence in relation to their kingdoms. Alexander I's insistence that he alone, and not some outside agency, should have authority in his kingdom would not have been unusual in this respect. The sense of being the ultimate source of authority for a named people or territory was what made a king a king. This was not compromised by submission to the king of England.

But this was to change. By 1216, as Rees Davies has made clear, submission to the king of England was seen in a different light; it implied that a subservient king was little different in essentials from

Studies, 20 (2000), 88-96. It may be significant that, only months before Alexander's appearance in Henry's army, David's position had received a huge boost when Henry arranged his marriage to Matilda daughter of Earl Waltheof and bestowed on David the title of earl and possession of Northampton-Huntingdon (note also that Earl Waltheof had been earl of Northumbria as well as Northampton and Huntingdon): Green, "David I and Henry I”, 6. 
a major lord within England itself. ${ }^{38}$ The first occasion in which the form and content of submission was radically reshaped was triggered by the capture of William I, king of Scots, at Alnwick on 13 July 1174 while invading northern England in support of a rebellion against Henry II. ${ }^{39}$ The first departure from previous practice in the relationship between kings of Scots and kings of England was the sustained humiliation endured by William, who was taken, 'shackled under the belly of a horse', to meet Henry II at Northampton on 26 July. ${ }^{40}$ William's discomfort continued when he was then taken in chains by King Henry from Portsmouth to Normandy, arriving on 13 August. ${ }^{41}$ He was held at Caen and Falaise, where he came to an agreement with his captor. The agreement was proclaimed publicly, and peace between the two kings formally restored, at Valognes on 8 December 1174. ${ }^{42}$ The second departure from earlier practice was that this agreement was enshrined in a written document. The document may have been drawn up initially at Falaise; it was certainly issued when the agreement was formally proclaimed at Valognes. ${ }^{43}$ The

38 Davies, "Keeping the natives in order", 220-1.

39 Gesta Regis Henrici Secundis Benedicti Abbatis, ed. W. Stubbs (2 vols, Rolls Series, London, 1867) [hereafter Howden, Gesta], i, 72; SAEC, 254. For what follows, see Davies, "Keeping the natives in order", 220-1.

40 Chronica Rogeri de Houedene, ed. W. Stubbs (4 vols, Rolls Series, London, 1868-71) [hereafter Howden, Chronica], ii, 64 (sub ventre equi compeditus). I am grateful to Dr Matthew Strickland for suggesting to me that this may be interpreted to mean that William was placed on a mare (perhaps an old nag) with his feet tied together. Dr Strickland has also pointed out to me that it may be inferred from Howden's account that William's humiliating presentation to Henry II was performed in front of a number of rebellious nobles who had recently submitted to Henry.

${ }^{41}$ The Flowers of History by Roger de Wendover, ed. Henry G. Hewlett (3 vols, Rolls Series, London, 1886-9), i, 101; SAEC, 255 n.5

42 Radulfi de Diceto Opera Omnia, ed. W. Stubbs (2 vols, Rolls Series, London, 1876), i, 396; SAEC, 258.

43 It survives in two early-thirteenth-century transcripts (Anglo-Scottish Relations, ed. Stones, 2-11). It was also copied by Roger of Howden (Howden, Gesta, i, 95-9; Howden, Chronica, ii, 80-2), who may have been present (Anglo-Scottish Relations, ed. Stones, 11 n.2). Howden gave Falaise as the place-date; the other copies have Valognes. For a solution to this problem (and endorsement of Stones' suggestion that Howden was present) see J. Gillingham, "The travels of Roger of Howden and his views of the Irish, Scots and Welsh”, Anglo-Norman Studies, 20 (1998), 151-69, at 
document had an even more awesome public airing when, according to the terms of the agreement, King William, together with a full gathering of Scottish prelates and nobles, met Henry II at York on 10 August 1175. In full view of his leading subjects, the document was sealed by King William and David, his brother and heir, and then read out. This was immediately followed by the third departure from previous submissions. Not only was William himself obliged to perform homage to Henry II and his son and heir, but so too were the assembled Scottish prelates and nobles, who became vassals of the king of England and his son, and swore fealty and allegiance 'against all men' to the extent that, should King William 'draw back' from the terms of the agreement, they would remain loyal to the king of England against their own king; the same oath was to be extracted from those bishops and barons who were absent. ${ }^{44}$ Such a direct intervention by an overlord in the relationship between a king and his people was unprecedented. So, too, was the stipulation that fugitives from justice in Scotland could be tried in England if they fled to England, while fugitives from justice in England must be handed over by the king of Scots and his vassals if they fled to Scotland. The final departure from previous submissions was that King William and his heirs were now deemed to hold Scotland as lieges of Henry II and his heirs. William's relationship with King Henry was now little different from that between an English tenant-in-chief and his king. From the moment of his capture William had been treated simply as a rebellious liegeman..$^{45}$

Political reality, as before, continued to play its part in shaping the terms of a submission: the opportunity for such a comprehensive victory for the king of England did not arise again for over a hundred years. The implications of subordination, however, were changing

157 n.54 (reprinted in idem, The English in the Twelfth Century: Imperialism, National Identity and Political Values (Woodbridge, 2000), 69-91, at 76 n.54).

${ }^{44}$ Anglo-Scottish Relations, ed. Stones, 4-9; Howden, Gesta, i, 95-9; Howden, Chronica, ii, 80-2; SAEC, 260-2.

45 On the treatment of rebels see Matthew Strickland, War and Chivalry. The Conduct and Perception of War in England and Normandy 1066-1217 (Cambridge, 1996), 240-57. Imprisonment was not uncommon; note also incidents in which the defeated party was humiliated in a way which involved horses or horsemanship (ibid., 253). 
fundamentally. Professor Davies has emphasised how the novel use of writing in this context was an essential element both in delimiting in painful detail the various and manifold consequences of William's submission, and also in offering the means to fulfill, potentially, the expectation that the agreement in all its clauses would define permanently the relationship between kings of Scots and kings of England. This could now only be redefined by another written agreement, which would explicitly supersede the earlier document. This is indeed what happened. After the coronation of Henry II's successor, Richard I, on 8 September 1189, William made arrangements to perform homage to the new king. When he met Richard at Canterbury on 2 December he succeeded in negotiating a new agreement, whereby William would do homage for his lands in England, and Richard would quitclaim fealty and allegiance for the kingdom of Scotland. ${ }^{46}$ The original document of the 'Treaty of

46 This is suggested by the statement that William has been released from all agreements and 'new charters' exacted by Henry II as a result of William's capture '...so that he shall do for us fully and completely whatever his brother Mael Coluim, king of Scotland, did of right, and ought to have done of right, for our predecessors...' (Anglo-Scottish Relations, ed. Stones, 13). Some doubt has been expressed about whether this amounted to a renounciation of 'English suzerainty', and that 'one suspects that to William the restoration of the status quo meant chiefly the return of Scottish castles...' (Anglo-Scottish Relations, ed. Stones, xxi). Roger of Howden, however, was in no doubt about what was intended (Howden, Gesta, ii, 98; Howden, Chronica, iii, 25: words in round brackets added in the Chronica): Richard I 'declared him [William] and all his heirs (free and) quit from him [Richard I] and kings of England concerning all allegiance and subjection concerning the kingdom of Scotland' (eum et omnes heredes suos (liberos et) quietos clamauit in perpetuum ab ipso et regibus Anglie de omni ligantia et subjectione de regno Scotie). Howden also included the text of the quitclaim in his chronicle (Howden, Chronica, iii, 25-6). Stones attempted to dismiss this by observing that 'chroniclers sometimes give very garbled reports of treaties' (Anglo-Scottish Relations, ed. Stones, xxi, n.3). This hardly does justice to Howden's work. John Gillingam has argued persuasively that this may be regarded as essentially the journal of 'a clerk with special expertise in Scottish and papal business, attached, as it were, to the Foreign Office, rather than to the Home Office or Treasury' (Gillingham, “The travels of Roger of Howden”, 168; idem, The English in the Twelfth Century, 90). Insofar as there was any ambiguity about what was owed for what by William to Richard, this can be explained by reference to the difficult issue of Northumberland: as Professor Duncan has observed in his discussion of the 'treaty', 'King Richard did not wish to restore William's claim to the earldom of Northumberland, and King William did not wish to lose it' 
Falaise'$^{{ }^{47}}$ was handed over to William, and presumably destroyed. This was all expressed in a new agreement, dated 5 December, which survives in the National Archives as a contemporary single sheet (although now, sadly, rather illegible). ${ }^{48}$ A new pattern had been established, in which major issues between the kingdoms were settled by negotiations which, if successful, culminated in a treaty. Unfortunately the text of the next treaty in 1209 (the 'peace' of Norham), or of its renewal in 1212, does not survive: according to the most recent discussion of them, however, the lordship of English kings over Scotland was 'scarcely an issue'. ${ }^{49}$ The experience of

(Duncan, Scotland: the Making of the Kingdom, 236); the reference back to the reign of Mael Coluim was 'a phrase of deliberate ambiguity since William had held Northumberland in the early part of Malcolm's reign, but had lost in the latter part' (A. A. M. Duncan, "John king of England and the kings of Scots" in King John: New Interpretations, ed. S. D. Church (Woodbridge, 1999), 247-71, at 250).

47 In the text itself of the 'treaty' it is described as convencio et finis, which Stones translated as 'treaty and settlement': Anglo-Scottish Relations, ed. Stones, 2-3. Its common designation as a 'treaty' (rather than 'agreement') may be justified by the fact that it took the form of a written document concerning relations between kings (although, strictly speaking, it might therefore be more appropriate to call it the 'Treaty of Valognes': see n.43 and references cited there).

48 Anglo-Scottish Relations, ed. Stones, 12 (entitled Carta regis Ricardi quam adquietauit regi Scocie homagium suum et castra expressa contra priores convenciones, 'Charter of King Richard, by which he quitclaimed to the king of Scots his homage and specified castles, counter to previous agreements'). Stones's edition (ibid., 12-17) is based on an early-thirteenth-century transcript. There was a price-tag of 10,000 merks. At an assembly at Musselburgh held shortly afterwords it was agreed that some of this sum, at least, would be raised by a general tax: this has been described as 'possibly the first time that anything like a national tax had been voted on in Scotland' (Regesta Regum Scottorum, ii, The Acts of William I, King of Scots 1165-1214, ed. G. W. S. Barrow with the collaboration of W. W. Scott (Edinburgh, 1971), 15). The burden was evidently widespread, and was regarded by those with little to give as sufficiently threatening that some, such as the men tied to estates of Scone abbey, fled from their homes rather than pay up (ibid., 333-4).

49 A. A. M. Duncan, "John king of England and the kings of Scots" in King John: New Interpretations, ed. S. D. Church (Woodbridge, 1999), 247-71, esp. 259-61, 2634: quotation at 268. Duncan is not, however, suggesting that the possibility of English lordship over Scotland was never considered, commenting (at 268) that 'John's demands for [Scottish] castles in 1209 shows that he then considered re-establishing the 1174 vassalage ended in 1189, but was persuaded to settle for two lassies and 15,000 marks'; indeed, he regards the 'treaty' of Falaise and submission at York as a formative experience in the emergence of a 'distinct political culture' in Scotland, so 
Welsh and Irish kings was not identical with William I's humiliation. The loose kind of overlordship was, however, eventually to became a thing of the past for them as much as for the king of Scots. ${ }^{50}$ In time they, too, discovered that submission to the king of England on the king of England's terms now meant a surrender to intrusive overlordship defined in writing. Even if these documents were subsequently cancelled or were otherwise overtaken by political circumstances, they could still survive and inform future thinking or political posturing for generations to come. Although it had formally been rescinded, the 'Treaty of Falaise' itself did not vanish into obscurity, but haunted Scottish claims to independence for centuries to come. ${ }^{51}$

In reality King Henry did not exploit fully the opportunities for direct lordship over Scotland afforded him by the 'Treaty of Falaise': he did not even establish English garrisons in all the castles which William was required to surrender to him according to its terms. ${ }^{52}$ Henry's jurisdiction was real enough, however: a writ of protection in Henry's name survives for Dunfermline, for example. ${ }^{53}$ It was also clear, from the language of the 'Treaty of Falaise' itself, that Scottish kingship was barely recognised: Professor Davies has pointed out that Scotland is referred to as a 'land' (terra), not a 'kingdom' (regnum), and that William's designation as 'king' contrasted with Henry's as 'lord king' ${ }^{54}$ The loss of independence was also keenly felt within King William's realm. A contemporary commented graphically on the recovery of independence in the 'Treaty' of Canterbury, declaring that 'by God's assistance, he [William] worthily and honourably removed

much so that he says (at 270) that 'if John in 1209 had bullied William into accepting feudal subjection, I doubt that the barons would have shown themselves as obediently submissive as had their fathers at York in 1175'.

50 Davies, "Keeping the natives in order", 220-1.

51 For extant copies, see n.43, above. It also survived in a near-contemporary abbreviation: Radulfi de Diceto Opera Omnia, ed. Stubbs, i, 396-7.

52 Duncan, Scotland: the Making of the Kingdom, 231.

53 Ibid., 232; G. W. S. Barrow, "A writ of Henry II for Dunfermline Abbey", SHR, 36 (1957), 138-43.

54 R. R. Davies, The First English Empire. Power and Identities in the British Isles 1093-1343 (Oxford, 2000), 14. 
his [Henry's] heavy yoke of domination and servitude from the kingdom of the Scots'. ${ }^{55}$

This was not, however, the first time in which the independence of the kingdom of the Scots had been called into question. The enforcement of a superior jurisdiction over Scotland had been attempted much earlier by archbishops of York and Canterbury. This was part of a wider process of consolidating the Church's authority which was initiated by Pope Leo IX (1049-54), and then galvanised by Pope Gregory VII (1073-85), who has aptly been described as 'the founding father of the high medieval papal monarchy' ${ }^{56}$ Before the mid-eleventh century the reality of episcopal jurisdiction and the operation of archiepiscopal authority had been variable, and sometimes negligible, with little or no intervention from the papacy. Gradually, in the period between Gregory and the next giant of the medieval papacy, Innocent III, this became firmed up into a clearly defined hierarchy of obedience embracing all the faithful. It was not always clear, however, what shape this structure should take. In some regions it needed to be established who should be archbishop, and/or what the limits of a diocese or province might be; another problem was the claims of primacy by one archbishop over others. ${ }^{57}$ The outcome of these disputes was determined chiefly by two opposing factors: one was the power of the written word and other precedents in defining permanently enduring arrangements, and the other was the

\footnotetext{
55 Chron. Melrose, 47; A. O. Anderson, Early Sources of Scottish History A.D.5001286 (2 vols, Edinburgh, 1922), ii, 322.

56 Robert Bartlett, The Making of Europe. Conquest, Colonization and Cultural Change 950-1350 (London, 1993; repr. 1994), 244.

57 See, e.g., Barrow, Kingship and Unity, 68-9, for a valuable general account; Frank Barlow, Durham Jurisdictional Peculiars (London, 1950), ix-x, on diocesan authority in England; Lucien Musset, "Les évêques normands envisagés dans le cadre Européen ( $\mathrm{X}^{\mathrm{e}}$-XII ${ }^{\mathrm{e}}$ siècles)", in Les évêques normands du XI siècle, edd. Pierre Bouet and Francois Neveux (Caen 1995), 53-65, at 53-6, for a brief survey of England, northern France and southern Italy; Gerd Tellenbach (trans. Timothy Reuter), The Church in Western Europe from the Tenth to the Early Twelfth Century (Cambridge, 1993), esp. 66, 72-3, on the pre-Gregorian papacy; Christopher Brooke, "The archbishops of St David's, Llandaff and Caerleon-on-Usk”, in Studies in the Early British Church, [ed. Nora K. Chadwick] (Cambridge, 1958), 201-33, esp. 212-13, on claims of primacy.
} 
crucial part played by immediate circumstances. ${ }^{58}$ As far as the former was concerned, the freedom of Scottish bishops from English archbishops seemed irredeemably compromised by the unambiguous testimony of so great an authority as Bede, who had clearly described Gregory the Great's intention that Britain should be divided between two archbishops, with northern bishops falling under the obedience of the archbishop of York. ${ }^{59}$ This had been the basis for the earliest decision taken towards firming up a structure of ecclesiastical authority in Britain. The occasion was a conference at Winchester and Windsor in 1072 presided over by King William I and a papal legate, where it was decided that the archbishop of York would have authority over all bishops north from the Humber 'as far as the outermost bounds of Scotland', and the archbishop of Canterbury would be acknowledged by York as primate of 'all Britain' . ${ }^{60}$

As the terms of this agreement made clear, the point at issue was the relationship between Canterbury and York, not the status of Scottish bishops. It is not surprising, therefore, that no Scottish bishops were present. The decision, nonetheless, had obvious implications for Scotland. Although the bishop of St Andrews had, probably since the beginning of the tenth century, been acknowledged as pre-eminent bishop of the kingdom (whatever this may have meant

58 The interplay of these factors can best be appreciated by examining case-studies. A particularly fine study of a famous case is Paula de Fougerolles, "Pope Gregory VII, the archbishopric of Dol and the Normans", Anglo-Norman Studies XXI, Proceedings of the Battle Conference 1998, ed. Christopher Harper-Bill (Woodbridge, 1999), 47-66. See also Michael Richter's important discussion of Canterbury's claims to primacy over Britain, in Canterbury Professions, ed. Michael Richter, The Canterbury and York Society vol. Ixvii (1973), liv-lxxiv, lxxxvi-xcvi. Present needs could, of course, inspire the creation of written precedents from the past: Brooke, "The archbishops of St David's, Llandaff and Caerleon-on-Usk”, 21331.

59 Bede's Ecclesiastical History of the English People, edd. Bertram Colgrave and R. A. B. Mynors (reprinted with corrections, Oxford, 1991), 104-7 (I.29). Another obstacle was the requirement in canon law that the seat of an archbishopric should equate with a Roman 'civitas-capital': see de Fougerolles, "Pope Gregory VII, the archbishopric of Dol and the Normans”, 52-3.

${ }^{60}$ Councils and Synods with Other Documents Relating to the English Church, vol.i (in two parts) 871-1204, edd. D. Whitelock, M. Brett and C. N. L. Brooke (Oxford, 1981), 591-3, 602. 
in practice), it was never going to be easy to obtain papal recognition of this as equivalent to metropolitan of a Scottish Church in the face of Bede's witness to Gregory the Great's intentions. The hopes of bishops of Glasgow, from Bishop John onwards, to escape York's jurisdiction must have seemed extremely remote. The lack of any suffragans meant that it could hardly have been considered for archiepiscopal status, and there is no evidence that this was ever contemplated. Moreover, there were recent examples of bishops of Glasgow who had been within York's obedience. ${ }^{61}$ It was hardly unexpected, therefore, that the papacy should have found York's claim to metropolitan authority over Scottish bishops to have been perfectly acceptable. The first extant letter from a pope to Scotland is that of Paschal II 'to the suffragans of York per Scotiam' written on the promotion of Gerard, bishop of Hereford, to the archbishopric of York in December 1100, in which the pope directed Scottish bishops to show obedience to Archbishop Gerard. ${ }^{62}$ This was ignored. The consecration of the formidable Archbishop Thurstan by Pope Calixtus II was the occasion of the start of a more vigorous papal letter-writing campaign insisting that York's authority be recognised in Scotland: a pair of letters was dispatched on 19 November 1119, followed by two addressed to King Alexander, another pair of letters dispatched on 15 January 1122, and a final missive to Bishop John of Glasgow. Successive popes wrote letters to the same effect, and with identical results: sustained prevarication or disobedience by the bishops of Glasgow and St Andrews, aided and abetted by their king. Only the bishop of Galloway yielded to York's authority, an indication of how

\footnotetext{
61 John Durkan, "Glasgow Diocese and the claims of York", Innes Review, 50 (1999), 89-101. There is no evidence, however, to support the view that 'Scottish bishops were normally consecrated by the archbishop of York': R. W. Southern, St Anselm and his Biographer. A Study of Monastic Life and Thought 1059-c.1130 (Cambridge, 1966), 135.

62 Robert Somerville, Scotia Pontificia. Papal Letters to Scotland before the Pontificate of Innocent III (Oxford, 1982), no.1; The Historians of the Church of Yprk and its Archbishops, ed. James Raine, vol.iii (Rolls Series, London, 1894), 22. For what follows, see Somerville, Scotia Pontificia, 3-10, 19-48 passim; A. D. M. Barrell, "The background to Cum universi: Scoto-papal relations, 1159-1192", Innes Review, 46 (1995), 116-38; D. E. R. Watt, Medieval Church Councils in Scotland (Edinburgh, 2000), 13-30.
} 
Galloway in this period was not bound closely to the kingdom of the Scots. ${ }^{63}$

It is highly likely that, had the bishop of St Andrews or the bishop of Glasgow made a profession of obedience at this stage, then the game would have been 'up' for them. ${ }^{64}$ The remaining Scottish bishops, whose sees and names were apparently unknown to the pope (and presumably York as well) until they were addressed personally by Pope Hadrian IV in 1155, would surely have fallen with St Andrews into York's obedience. What kept the cause of Glasgow and St Andrews and the others alive was a combination of politics and sheer good fortune. The most dangerous period was when a new bishop of St Andrews or bishop of Glasgow needed to be consecrated. Glasgow was particularly lucky that this coincided with vacancies in the archbishopric of York: both Bishop John and his successor Herbert were consecrated by the pope himself. This pattern was then continued even when there was no vacancy at York, when Herbert's successor, Engelram, was consecrated by Pope Alexander III and Engelram's successor, Jocelyn, was consecrated at Clairvaux by a papal legate. ${ }^{65}$

63 Richard D. Oram, "In obedience and reverence: Whithorn and York c.1128c.1250", Innes Review, 42 (1991), 83-100: at 95-6 there is a discussion of evidence of the involvement of kings of England in the appointment of bishops of Galloway in the twelfth and early thirteenth centuries.

${ }^{64}$ Their most important weapon was the inability of the archbishop of York to make good his claims. Also, judging from the Irish and Welsh situations, occasional professions of obedience before independence became an issue were not fatal; it was rather different, however, if a profession of obedience was secured subsequently. The case of St David's is particularly instructive, in which the profession of obedience and promise not to promote St David's claims obtained by Canterbury from Bishop Bernard's successors effectively dealt a fatal blow to the cause of an archbishopric of St David's, despite the efforts of Gerald of Wales to revive them 1198-1203. See in general Marie-Thérèse Flanagan, Irish Society, Anglo-Norman Settlers, and Angevin Kingship: Interactions in Ireland in the Late Twelfth Century (Oxford, 1989), ch.1, and Davies, The Age of Conquest, 190-1. The initial attempt by Bishop Bernard (1115-48) to gain papal recognition for St David's independence was effectively stymied by his profession to the archbishop of Canterbury and his behaviour as suffragan before his campaign for the pallium began sometime during the pontificate of Honorius II (1124-30): see Richter, Canterbury Professions, Ixxxvii-xciii; M. Richter, "Canterbury's primacy in Wales and the first stage of Bishop Bernard's opposition”, Journal of Ecclesiastical History, 22 (1971), 177-89.

65 Duncan, Scotland: the Making of the Kingdom, 261. 
The fate of St Andrews was decided more by politics. Its claim to archiepiscopal status meant that it could gain attention as part of the bigger picture of how the ecclesiastical structure of Britain and Ireland should be established. It has been pointed out, for example, that King David I in 1139-40 had contact with both Mael Maedoc Ua Morgair (St Malachy) and Bishop Bernard of St David's, who at that time were each seeking papal recognition for independent churches respectively in Ireland and Wales; ${ }^{66}$ the success of one campaign against English metropolitan authority could have had positive implications for the chances of others. ${ }^{67}$ The claim of St Andrews to archiepisciopal status, moreover, proved a crucial bargaining counter which could be used to persuade the archbishop of York to settle for a temporary compromise. Bishop Robert, for example, had been elected at the end of the reign of Alexander I, who died in April 1124. The new king, David, attempted to settle the matter by obtaining a pallium for St Andrews probably when he met the first papal legate to visit Scotland sometime in July or August 1125. Bishop John of Glasgow was later dispatched to the Curia to press the case, arriving by Christmas 1125 . In the end both sides agreed to shelve their claims temporarily when, at the behest of Henry I and David I, Archbishop Thurstan consecrated Robert early in 1127 without a profession of obedience. The role of the kings highlights another political dimension, for Henry I had been grateful for David I's support in securing the recognition of his daughter Matilda as his heir at Christmas in 1126. ${ }^{68}$ When Bishop Robert died in 1159, the possibility of a pallium for St Andrews was raised again. ${ }^{69}$ On this occasion, however, it has been suggested that papal politics played an important part in securing a further

\footnotetext{
${ }^{66}$ It has been suggested that David I 'concerted the great attack on the Canterbury primacy from Scotland, Wales and Ireland in the 1140s': Denis Bethell, "English monks and Irish reform in the eleventh and twelfth centuries", Historical Studies: papers read before the Irish Conference of Historians, VIII Dublin 27-30 May 1969, ed. T. D. Williams (Dublin, 1971), 111-35, at 132. I am grateful to Professor Davies for referring me to this paper. See also G. W. S. Barrow, "King David I and the Honour of Lancaster”, English Historical Review, 70 (1955), 85-9, esp. 89.

67 Flanagan, Irish Society, Anglo-Norman Settlers, and Angevin Kingship, 32-8.

68 Green, "David I and Henry I", 15-16.

69 Watt, Medieval Church Councils, 18-19. St Andrews' claim had also been raised in $1151 / 2$.
} 
postponement of a final judgement on this and York's claims. Pope Alexander III, who succeeded Hadrian IV in 1159, was faced by a schism in Rome, and may have been reluctant to make a decision which could result in a loss of support. ${ }^{70}$

During the pontificate of Alexander III (1159-81) the claims of Scottish bishops and York became more evenly matched in papal eyes. It was the accident of political events, however, which provoked the papacy to adopt a distinctly anti-York, pro-Scottish position for the first time. The catalyst was the loss of Scottish independence following the 'Treaty of Falaise'. The final stage in procuring full recognition of English jurisdiction over Scotland was at a council in Northampton, in January (or February) 1176, where Henry II attempted to force the subjection of Scottish bishops. ${ }^{71}$ The bishops escaped from this awkward spot when the archbishops of York and Canterbury reopened the dispute about which of them should be their metropolitan. The Scots swiftly sent a delegation to Pope Alexander who came to their assistance with the bull Super anxietatibus on 30 July, 1176. Alexander insisted that the 'bishops of Scotland' should regard the pope as their metropolitan until the issue was reopened by York, at which point a lasting resolution was anticipated. ${ }^{22}$ The pontiff left no doubt what he thought of recent events, describing these as an affront to God and to Alexander himself: 'kings and princes', he declared, 'had no right to arrange ecclesiastical matters' ${ }^{73}$ York's defeat was not yet inevitable: it has been argued that Bishop Jocelin in 1179 sought a reissue of Alexander III's protection for Glasgow, originally granted in 1175, because of the pope's return to a more sympathetic view of York's position. ${ }^{74}$ Independence was only finally guaranteed with the bull Cum universi, usually dated to 1192, although a case has been made for $1189 .{ }^{75}$

70 Barrell, "The background to Cum universi”, 117.

71 Councils and Synods, i, edd. Whitelock, Brett and Brooke, 997-8.

72 Somerville, Scotia Pontificia, no.80. Early in 1175, at or near the time of Bishop Jocelin's consecration, the pope granted a privilege of protection to Glasgow, which was described as 'our special daughter with no intermediary'. Somerville, Scotia Pontificia, no.76.

73 Somerville, Scotia Pontificia, no.80 (at p.79).

74 Barrell, "The background to Cum universi", 121-2.

75 Ibid., 128-37. 
Although the struggle of Scottish bishops to escape the attentions of archbishops of York and Canterbury is clearly relevant to the general theme of the origins of Scottish independence, it might not seem immediately obvious that it was in this context that the independence of the kingdom was first conceived. It is generally recognised that, before the Gregorian Age, the Church was closely identified with secular power. That this was true in a Scottish context can readily be surmised by the fact that that the title of the chief cleric paralleled that of the king: 'bishop of Scots' (episcopus Scottorum; epscop Alban) and 'king of Scots' (rex Scottorum; rí Alban). Nevertheless, the status of the Scottish kingdom has typically been regarded as essentially about the relationship between kings, rather than prelates. There is no shortage of accounts of how ecclesia Scoticana achieved its freedom; these, however, appear either in articles or books devoted specifically to Church History, or in designated sections on the Church in more general works. ${ }^{76}$ It is hardly unexpected, therefore, that Cum universi does not appear in the indexes of two of the most important books on the history of the period 1100-1300 published in recent times, even though both have as their principal theme the English impact on Britain and Ireland and the response of societies at the receiving end of English domination. ${ }^{77}$ Both books are avowedly secular in outlook; the claims of Canterbury and York over Scotland and elsewhere are not ignored, but they are not accorded any prominence. ${ }^{78}$

\footnotetext{
76 There are numerous examples: the most recent is Robert Bartlett, England under the Norman and Angevin Kings 1075-1225, The New Oxford History of England (Oxford, 2000), 68-102, at 94-5. An important contribution to the study of Church and kingship is Raymonde Foreville, L'Eglise et la Royauté en Angleterre sous Henri II Plantagenet (1154-1189) ([Paris], 1943): note especially her comment (at 504), concerning the Scottish struggle against the claims of Canterbury and York, that 'the opposition of the [Scottish] bishops already sometimes assumed the character of a genuine national resistance'.

Davies, Domination and Conquest, ix; Robin Frame, The Political Development of the British Isles 1100-1400 (Oxford, 1990), 4.

${ }_{78}$ Frame, The Political Development of the British Isles, 18, 52. The issue is given a more integrated treatment, however, in Flanagan, Irish Society, Anglo-Norman Settlers, and Angevin Kingship, chap.1, and Davies, The First English Empire, chap.2.
} 
It has been remarked by Professor Geoffrey Barrow that Pope Alexander III was probably 'the first person to link the concept of liberty to the kingdom of Scotland' ${ }^{79}$ The occasion was a letter written in 1180 to King William in which Alexander warned the king to stop harassing the canonically elected bishop of St Andrews in favour of his own candidate. ${ }^{80}$ The pope did not mince his words. In an obvious reference to his recent decision in Super anxietatibus to forbid the archbishop of York from exercising metropolitan authority in Scotland, Alexander declared that 'as we have laboured that your kingdom should have liberty, so we shall take care that it reverts to its original subjection' ${ }^{81}$ The idea that the kingdom's status was at stake in the dispute with York and Canterbury, however, was not new. The York historian, Hugh the Chanter, for example, described how Archbishop Thurstan in December 1125 thwarted the attempt to gain a pallium for St Andrews by persuading the pope that 'Scotland was part of the kingdom of England, and that the king of Scotland was the man of the king of England for Scotland' ${ }^{82}$ This is the earliest recorded instance in which the submission of kings of Scots was interpreted in such a way, clearly anticipating a central aspect of the 'Treaty of Falaise'. It is also apparent, however, that the independence of the Scottish kingdom was regarded as an issue in the disagreement between Alexander I and Eadmer, bishop-elect of St Andrews. In his last letter to Alexander, Eadmer, writing from Canterbury, insisted that it had not been his intention 'to detract in any way from the freedom and dignity of the kingdom of the Scots', and declared that he

G. W. S. Barrow, “The idea of freedom in late medieval Scotland”, Innes Review, 30 (1979), 16-34, at 18.

${ }^{80}$ On the dispute over the bishopric of St Andrews, see Duncan, Scotland: the Making of the Kingdom, 270-4.

81 sicut laboravimus ut regnum tuum libertatem haberet, sic dabimus studium ut in pristinam subjectionem revertatur: Howden, Gesta, i, 263; Howden, Chronica, ii, 212.

${ }^{82}$ Scociam de regno Anglie esse, et regem Scottorum de Scocia hominem esse regis Anglie: Hugh the Chanter, The History of the Church of York 1066-1127, ed. and trans. Charles Johnson, rev. ed. M. Brett, C. N. L. Brooke, and M. Winterbottom (Oxford, 1990), 212; "History of Four Archbishops of York by Hugh the Chanter", in The Historians of the Church of Yprk and its Archbishops, ed. James Raine, vol.ii (Rolls Series, London, 1886), at 215; SAEC 161. 
would no longer refuse Alexander's wishes. ${ }^{83}$ This is almost certainly the earliest explicit reference to the kingdom's liberty.

All these references to Scottish independence are from nonScottish sources. Nonetheless, there is no reason to doubt that Scottish kings and prelates would also have regarded York's and Canterbury's claims to metropolitan authority in a similar light. It will be recalled that Eadmer potentially affords us unparalleled access to Alexander I's thinking on this subject, and that, according to him, Alexander I saw the threat of Eadmer's consecration and obedience to the archbishop of Canterbury as not simply a matter of the status of the church of St Andrews, but in terms of his kingdom's subjection to Canterbury. When the first known request was made at the Curia for St Andrews to be recognised as an archbishopric, in Christmas 1125, we are told by Hugh the Chanter that it was argued 'by some people' (presumably the delegation from David I) that Scotland was not part of the kingdom of England. ${ }^{84}$ It will be recalled that Archbishop Thurstan persuaded the pope otherwise. It was the Scottish delegation, however, who apparently raised this as the central issue.

It is now possible, however, to gain a clearer impression of Scottish opinion from an early stage in this dispute thanks to the recent discovery of two manuscript witnesses of version 'A' of the St Andrews foundation legend. ${ }^{85}$ This text, which was plainly written at St Andrews, had hitherto been known in full only in Archbishop James Ussher's Britannicarum Ecclesiarum Antiquitates, published in $1639 .{ }^{86}$ Unfortunately the only previously known manuscript witnesses

83 derogare libertati vel dignitati regni Scottorum: Eadmeri Historia Novorum, ed. Rule, 300; SAEC 153.

${ }^{84}$ Hugh the Chanter, The History of the Church of York, ed. and trans. Johnson, rev. edn., 212. For the three parties present at the Curia (those of David I, York and Canterbury) see Donald Nicholl, Thurstan, Archbishop of York (1114-1140) (York, 1964), 97-8.

85 For what follows, see Dauvit Broun, "The church of St Andrew and its foundation legend in the early twelfth century: recovering the full text of Version A of the foundation legend", in Kings, Clerics and Chronicles in Scotland. Essays in Honour of Marjorie Ogilvie Anderson on the Occasion of her Ninetieth Birthday, ed. Simon Taylor (Dublin, 2000), 108-14. A new edition, with a fuller discussion, will be published in Dauvit Broun and Simon Taylor, The Church of St Andrew and its Foundation Legends (forthcoming).

86 James Ussher, Britannicarum Ecclesiarum Antiquitates (Dublin, 1639), 648-51. 
(one from the late twelfth century, the other mid-fourteenth century) were of a shorter version, minus the last fifth of the text printed by Ussher ${ }^{87}$ Ussher's text also showed a number of significant unique readings. It has not been surprising, then, that in the absence of any obvious way to verify the authenticity of Ussher's text as a twelfthcentury recension of version ' $A$ ' of the foundation-legend, scholars have attached little or no significance to it. The two new manuscript witnesses have changed that. One is late twelfth-century in date, and the other might be either just before or after $1200 .{ }^{88}$ Both contain the full extent of the text printed by Ussher, and share many of his variant readings. As a result, a strident statement of St Andrews' archiepiscopal status is rescued from scholarly limbo.

The first point to note in the restored text is that the significance of St Andrews in the kingdom is made plain. We are told that the Pictish king, Hungus (almost certainly Unust son of Uurgust who died in 761), 'gave this place and this city to Almighty God and to St Andrew the apostle in freedom for ever, that it might be the head and mother of all churches which are in the kingdom of the Scots'. In the shortened version of the legend the contemporary force of this statement has been diluted by referring to the kingdom of the Picts rather than the kingdom of the Scots. The most striking part of the text, however, is at the end, where the main message is hammered home:

And so the archiepiscopacy of all Scotia ought to be [exercised] from this city, where the apostolic seat is. No bishop ought to be ordained in Scotia without the approval of the elders of this place. Indeed, in relation to the first Rome this is the second; this is a preeminent city of refuge; this is the city of cities of Scotia, to which Our Lord gave these

87 M. O. Anderson, "St Andrews before Alexander I", in The Scottish Tradition, ed. G. W. S. Barrow (Edinburgh, 1974), 1-13: witnesses of the 'A' version of the legend are discussed at 9-10. The fourteenth-century manuscript of this shorter version, Paris, Bibliothèque nationale Latin 4126 (fos.31r-32r), has been the basis of all previous editions of this legend (most recently M. O. Anderson, Kings and Kingship in Early Scotland, 2nd edn (Edinburgh, 1980), 258-60). No translation has yet been published.

${ }_{88}$ London, BL Arundel 36 (fos 15vb-16va: pencil foliation) and London, BL Cotton Tiberius D iii (fos 93rb-94ra). The latter was badly damaged by fire on 23 October, 1731. 
supports to help: that is, Archbishop Giric, Mac Bethad, and Gregoir, with other brothers of theirs.

St Andrews' archiepiscopal status is portrayed as a fact of life; moreover, it is not simply an archbishopric, but a 'second Rome', due to its special association with St Andrew. The text relates how his relics came to be housed at St Andrews, and how pilgrims from far and wide are drawn to them for a range of cures. The strident selfconfidence of this statement, which has clearly been written in St Andrews itself, may arouse suspicion that it was produced when St Andrews' status was in question. These suspicions are strengthened considerably by the mention of Archbishop Giric, who appears (with some other names) between Fothad (died 1093) and Turgot (elected 1107 ) in the most accurate witness of the late-medieval list of early bishops of St Andrews. ${ }^{89}$ His likely floruit of ca 1100 therefore coincides with the first extant papal communication with Scotland in which, it will be recalled, obedience to York was urged. It may be surmised that this was the occasion which provoked the writing of version A of the St Andrews foundation-legend. If so, it can be read as a bold attempt to justify St Andrews' position as the premier see of the kingdom and to protect its freedom from any outside authority (except Rome itself). Seen in this light, it is also a statement of the kingdom's jurisdictional integrity: the first declaration of the kingdom's independent status in relation to another kingdom (specifically England).

Long before the loose overlordship of the king of England threatened to become more direct and intrusive, the status of the Scottish kingdom in relation to England had been challenged and

\footnotetext{
${ }^{89}$ Against normal expectations this is not Bower's Scotichronicon (where the list appears in book VI, ch. 24: Scotichronicon by Walter Bower in Latin and English, vol.iii, edd. and trans. John and Winifred MacQueen and D. E. R. Watt (Edinburgh, 1995), 342-5), but in Bower's own abbreviation of his great work, which is known to scholarship as the 'Book of Coupar Angus' (Edinburgh, NLS Adv. 35.1.7, p.433). This has not been published before (although most of it was given by Walter Goodall in his edition of Scotichronicon: Joannis de Fordun Scotichronicon cum Supplementis et Continuatione Walteri Boweri, ed. W. Goodall, 2 vols (Edinburgh, 1759), i, 339, $\left.\mathrm{n} .{ }^{*}\right)$. It will be discussed, edited and translated in Broun and Taylor, The Church of St Andrew (forthcoming).
} 
stoutly defended. The freedom of Scottish bishops from York (or Canterbury) was not simply about ecclesiastical jurisdiction. It was essentially about the kingdom's freedom. But this was not simply freedom in the sense of freedom from paying tribute. For the first time the issue was who exercised authority over Scottish society. This was the beginning of independence in the sense we can recognise today. It was in the context of the Church that the ideal of an independent kingdom was first consciously articulated.

In due course Scottish independence also became a key issue in relations between kings of Scots and kings of England (as Professor Davies has shown). The ideal of the jurisdictional integrity of the Scottish realm ultimately had the potential to affect relationships within Scotland, too. This, however, was still quite underdeveloped by the end of the twelfth century: the kingdom comprised not one 'country', but several. Again, it was in the context of the Church that this was most keenly exposed as an unresolved dimension of Scottish independence. Cum universi was not only a defeat for York, but put paid to St Andrews' hopes of a pallium for the foreseeable future. Every Scottish diocese was to owe obedience to the pope directly (except for Galloway which was acknowledged to be within the province of York). This represented a particular triumph for the bishopric of Glasgow, which thereby had its independence secured against all the odds..$^{90}$ The ideal of Scotland's independence may have first been articulated at the beginning of the twelfth century; the emergence of a self-consciously sovereign kingdom corresponding to a single country had, however, hardly begun to emerge by the century's end..$^{91}$ By 1200 it had been established, in a way which had every prospect of enduring, that Scotland was not part of England; but

\footnotetext{
90 The issue of Glasgow's independence, and how this related to ideas of kingdom and country, will be explored further in my Govan lecture in March 2002, The Welsh Identity of the Kingdom of Strathclyde, ca 900-ca 1200.

91 See also Broun, "The seven kingdoms in De situ Albanie", in Alba. Celtic Scotland, edd. Cowan and McDonald, esp. 42.

I am very grateful to Professor R. R. Davies for commenting on a draft of this article, to Professor G. W. S. Barrow, Dr Thomas Owen Clancy and Alex Woolf for casting a careful eye over the (nearly) finished product, to Neil Strevett for discussing the failed royal meeting at Gloucester in 1093, and to Dr Nerys Ann Jones for her constant support. I remain, as ever, responsible for any blemishes and misjudgements.
} 
beyond that there was as yet no simple answer to what 'Scotland' meant. 